\title{
Analgesic Activity of Methanol Leaf Extract of Tamarindus Indica Plant in Mice and Rats
}

\author{
Salisu Muhammad Highab ${ }^{{ }^{*}}$, Ismaila Raji ${ }^{1}$, \\ Abdulhakim Abubakar', Fatima Ismail Hassan ${ }^{2}$ \\ ${ }^{1}$ Department of Pharmacology and Therapeutics, \\ Faculty of Basic Medical Sciences, \\ College of Medicine and Health Sciences, \\ Federal University Dutse, \\ Jigawa State, Nigeria. \\ ${ }^{2}$ Department of Pharmacology and Therapeutics, \\ Faculty of Pharmaceutical Sciences, \\ Ahmadu Bello University, \\ Zaria, Kaduna State, Nigeria. \\ Email: smhighab@gmail.com
}

\begin{abstract}
Tamarindus indica has several folkloric uses in the treatment of various ailments. This study evaluated the analgesic activity of methanol leaf extract of Tamarindus indica (MLETI) in mice and Wistar rats. Acute toxicity studies were conducted using both the modified method of Lorke and OECD 425 guidelines. The analgesic activity was tested using acetic acid-induced writhing test, hot plate and formalin-induced hind-paw licking. Glycosides, flavonoids, saponins, alkaloids, reducing sugars, steroids and terpenoids were identified from the MLETI following phytochemical analysis. The $L D_{50}$ was above $5000 \mathrm{mg} / \mathrm{kg}$ in both species. Compared to controls, the MLETI (50, 100, and 200 $m g / k g)$ produced significant $(p<0.001)$ dose-dependent reductions $(33.6 \%, 35.5 \%$ and $47.2 \%)$ in acetic acid-induced writhes in the treated mice. MLETI also produced significant $(p<0.005)$ analgesic effect with the hot plate-induced pain and significantly $(p<0.001)$ inhibited formalin-induced pawlicking response in test rats compared to controls. This was higher in the second phase compared to the early phase at all the tested doses. The methanol leaf extract of Tamarindus indica possesses analgesic activity. It also contained glycosides, flavonoids, saponins, alkaloids, reducing sugars, steroids and terpenoids, some/all of which may be responsible for the observed centrally and peripherally mediated analgesic activities.
\end{abstract}

Keyword: Analgesic, Fabaceae, mice, Tamarindus indica, Wistar rats

\section{INTRODUCTION}

Tamarindus indica (T. indica) is derived from Arabic word tamar-hindi meaning "Date of India". Several early medieval herbalists and physicians wrote the name as tamar-indi, but it was later written as "tamarindus" (Khan and Muheet-e-Azam, 2012). Common and indigenous names of T. indica plant are: English: Tamarind or Amarind tree, Hausa: Tsamiya, Fulfulde: Gyatame, Yoruba: Awin or Ajagbon, Igbo: Icheku Oyibo, Ghanaians: Dawadawa. 
T. indica is a leguminous tree that belongs to the dicotyledonous (Fabaceae) family with the subfamily - Casalpiniaceae, the third largest family of flowering plants with a total of 727 genera and 19,327 species (Lewis and Elvin-Lewis, 2003). Tamarind belongs to the genus Tamarindus which has a single species and has long been cultivated on the Indian subcontinent as an indigenous plant (Abubakar, 2010) and now widely distributed in the tropical and subtropical areas as a tree-type of plant indigenous to tropical Africa (Diallo et al., 2007). The plant grows well in all soil types and in the full sun. It is highly resistant to drought, aerosol and salt. In Africa, it is commonly found in woodlands and it is well adapted to the arid and semi-arid zones. It tolerates temperature of up to $47^{\circ} \mathrm{C}$ and is very sensitive to frost (Coronel, 1991).

Tamarind is used extensively in herbal medicine in many parts of the world. Almost all the parts of the plant have medicinal properties (Meher et al., 2014; Naeem et al., 2017; Azad, 2018; Abdelrahman, and Mariod, 2019; Chimsah et al., 2020). In Nigeria, tamarind is freely and readily available and has been reported to be among the recipe used in the treatment of cold, fever, stomach disorder, diarrhea, jaundice and as a skin cleanser (Ferrara, 2005; Meher et al., 2014). It is applied on inflammation, mixed with salt as a liniment for rheumatism and used to gargle for sore throat. It also relieves pains, reduces secondary bacterial infection and promotes healing (Fabiyi et al., 1993).

Other reports in literature suggest that specific parts of the plant have been used in traditional medicine (Abdelrahman, and Mariod, 2019). The leaves are used to reduce inflammatory swelling, treat tumors, ringworms, blood diseases, small pox, ophthalmic and other ocular disease, ear ache and snake bite. The flowers are used to stimulate appetite and treat urinary discharges as well as bad odour due to perspiration. The fruit pulp is used as a laxative, tonic to the heart, anthelmintic and for healing wounds and fractures, treating biliousness, bile disorders and to stimulate appetite. The bark has astringent properties, and it is also used to treat ulcer, liver complaints (jaundice) and diabetes mellitus (Naeem et al., 2017; Azad, 2018; Abdelrahman, and Mariod, 2019; Chimsah et al., 2020). Thirteen (13) distinct compounds which include linonene and benzylbenzoate have been isolated from the leaves (Khanzada et al., 2008). This research therefore evaluated the analgesic activity of the methanol leaf extract of $T$. indica plant in mice and Wistar rats.

\section{METHODOLOGY}

\section{Experimental Animals}

Adult Swiss albino mice, weighing between 25-35g and Wistar rats of both sex, weighing between 150-200 $\mathrm{g}$ and 3-5 months old were obtained from National Institute for Pharmaceutical Research and Development (NIPRD), Idu FCT, Abuja. They were housed in cages and keep in a well-ventilated room under standard condition of temperature and light; in the Animal House of National Institute for Pharmaceutical Research and Development (NIPRD) Idu, Abuja. They were allowed to acclimatize to laboratory conditions for two weeks prior to the study, fed on commercial Pfizer grower's mash prepared in pellets and given water ad libitum except when fasting was necessary in the course of the study. All experiments were performed in accordance with the "principles of laboratory animal care" (NIH publication, 1985) and NIPRD standard operating procedures.

\section{Drugs and Chemicals}

The drugs and chemicals used in the study include; pentazocine, ketoprofen, pyrimethamine, chloroquine phosphate, formaldehyde (Sigma Aldrich), alcohol, acetic acid, Giemsa (Philip Harris Ltd), and chloroform (May and Baker). Absolute methanol, 
concentrated hydrochloric acid, ferric chloride, sulphuric acid, picric acid, Wagner reagent and Dragendroff reagent used were manufactured by British Drug House (BDH) Ltd Poole, England.

\section{Collection and Identification of Plant Material}

The fresh leaves of T. indica were collected from Getso, in Gwarzo Local Government Area of Kano state, Nigeria, in August, 2018. The whole plant was identified and authenticated at the Herbarium Section of the National Institute for Pharmaceutical Research and Development (NIPRD), Idu, Abuja. A voucher specimen (number: H6782) was given and deposited in the NIPRD Herbarium for future reference.

\section{Preparation of Methanol Leaf Extract}

The leaves of the T. indica plant were pruned while fresh and air dried at room temperature for two weeks. The dried leaves were reduced to a fine powder using wooden mortar and pestle. The powdered leaves were extracted in $70 \%$ methanol using a Soxhlet apparatus for 72 hours. The extract obtained was concentrated using rotary evaporator and evaporated to dryness in a water bath at $45^{\circ} \mathrm{C}$. The extract was weighed, stored in an air tight container and refrigerated prior to use.

\section{Qualitative Determination of Phytochemicals in MLETI}

The preliminary phytochemical analysis was carried out on the MLETI to identify the presence or absence of organic metabolites according the methods described by Evans (2009) and Sofowora (1993).

\section{Quantitative Determination of Phytochemicals in MLETI}

\section{Alkaloid determination}

Ten (10) gram of the sample was weighed into a $250 \mathrm{ml}$ beaker and $100 \mathrm{ml}$ of $10 \%$ acetic acid in ethanol was added, covered and allowed to stand at room temperature for $4 \mathrm{~h}$ before it was filtered through Whitman No.1 filter paper. The filtrate was concentrated on a water bath to one quarter of the original volume. Then concentrated ammonium hydroxide was added drop-wise to the extract until precipitation was completed by obtaining full turbidity. This whole solution was allowed to settle and filtered through a known weighted filter paper. The precipitate was washed with dilute ammonium hydroxide solution. The residue is the alkaloid, which was dried in oven at $100^{\circ} \mathrm{C}$ for an hour, cooled in a desiccator and weighed. The weight of the alkaloid was determined by difference and expressed as percentage of the sample analyzed (Harborne, 1973).

\section{Flavonoids determination}

Ten (10) gram of the plant sample was hydrolyzed by boiling in $100 \mathrm{mls}$ of $2 \%$ hydrochloric acid solution for 35 minutes. The whole solution was filtered through Whitman filter paper No $42(125 \mathrm{~mm})$. The filtrate was treated with ethyl acetate drop wise twice until in excess. The precipitate flavonoid was recovered by filtration through a pre weighed filter paper, which was dried in an oven at $100^{\circ} \mathrm{C}$ for 30 minutes. It was cooled in a desiccator and reweighed. The weight of the flavonoids was considered as the difference in weight, which was expressed as percentage of the analysed sample (Bohm, 1998).

\section{Tannins determination}

The Follins - Dennis Spectrophotometric and Van- Burden and Robinson methods were used to determine the Tannin content of MLETI. For the Follins - Dennis Spectrophotometric method, a measured weight of the test sample $(1.0 \mathrm{~g})$ was dispersed in 
$10 \mathrm{ml}$ distilled $\mathrm{H}_{2} \mathrm{O}$ and agitated. This was left to stand for 30 minutes at room temperature being shaken every 5 minutes. At the end of the 30 minutes, it was centrifuged and the filtrate gotten. $2.5 \mathrm{ml}$ of the supernatant (extract) was dispersed into a $50 \mathrm{ml}$ volumetric flask. Similarly $2.5 \mathrm{ml}$ of standard tannic acid solution was dispersed into a separate $50 \mathrm{ml}$ flask. A $1.0 \mathrm{ml}$ Folin Denis reagent was measured into each flask followed by $2.5 \mathrm{ml}$ of saturated $\mathrm{Na}_{2} \mathrm{CO}_{2}$ solution. The mixture was diluted to mark in the flask $(50 \mathrm{ml})$ and incubated for 90 minutes at room temperature. The absorbance was measured at $760 \mathrm{~nm}$ using a 'Genway model 6000 electronic spectrophotometer. The experiment was repeated three times to get an average (Pearson, 1976). Another $500 \mathrm{mg}$ of the sample was weighed into a $50 \mathrm{ml}$ plastic bottle: $50 \mathrm{ml}$ of distilled water was added and shaken for $1 \mathrm{~h}$ in a mechanical shaker. This was filtered into a $50 \mathrm{ml}$ volumetric flask and made up to the mark. Then $5 \mathrm{ml}$ of the filtrate was pipette out into a test tube and mixed with $2 \mathrm{ml}$ of $0.1 \mathrm{M} \mathrm{FeCl}_{3}$ in $0.1 \mathrm{~N} \mathrm{HCI}$ and $0.008 \mathrm{M}$ Potassium ferrocyanide. The absorbance was measured at $120 \mathrm{~nm}$ within $10 \mathrm{~min}$ (Walker et al., 2006).

\section{Cyanogenic glycosides determination}

The extraction was carried out according to Wang and filled method as described by Onwuka, (2005). A portion (5 g) of the plant material was made into paste and dissolved in $50 \mathrm{ml}$ of distilled water. The extract was filtered and the filtrate was used for cyanide determination. To $1 \mathrm{ml}$ of the sample filtrate, $4 \mathrm{ml}$ of alkaline picrate was added and absorbance was recorded at $550 \mathrm{~nm}$ and cyanide content was extrapolated using a cyanide standard curve.

\section{Saponins determination}

The gravimetric method of the Association of Official Analytical Chemists (Williams, 1984) employing the use of a Soxhlet extractor and two different organic solvents was used. A $10 \mathrm{~g}$ of dry ground sample was weighed into a thimble and transferred into a Soxhlet extractor chamber fitted with a condenser and a flat bottom flask. Five hundred (500) milliliters of acetone was poured into the flask. The sample was exhaustively extracted of its lipid and interfering pigments for 3 hours by heating the flask on a hot plate and the solvent distilled off. This was the first extraction. For the second extraction, a pre-weighed round bottom flask was fitted into the Soxhlet apparatus (bearing the sample containing thimble) and methanol poured into the flask. The methanol was enough to cause a reflux. The saponins were then exhaustively extracted for 3 hours by heating the flask on a hot plate after which the solvent was distilled off. The flask was re-weighed. The difference between the final and initial weights of the flask represented the quantity of saponins extracted.

\section{Acute Toxicity Study}

Lorke method for acute toxicity study.

Acute toxicity study was conducted using the modified method of Lorke, (1983). In the first phase, 9 of each of the animals were divided into three groups of three mice each and after overnight fasting, were treated with the extract at doses of 10,100 and $1000 \mathrm{mg} / \mathrm{kg}$ orally via gavage. The animals were observed for the first four hours and every 24 hours after treatment, for signs of toxicity and death, for 14 days.

In the second phase, the mice were treated with the extract at doses of 1600, 2900 and $5000 \mathrm{mg} / \mathrm{kg}$ orally, after overnight fasting based on the result of the first phase. The mice were observed for the first four hours and every 24 hours for signs of toxicity and death for 14 days as in the first phase. 
The median lethal dose $\left(\mathrm{LD}_{50}\right)$ was calculated as the geometric mean of the lowest dose that caused death and the highest dose at which all the animals survived. This is expressed mathematically as:

$$
\begin{aligned}
\mathrm{LD}_{50} & =\sqrt{\mathrm{A} \times \mathrm{B}} \\
\text { Where } \mathrm{A} & =\text { minimum lethal dose } \\
\mathrm{B} & =\text { maximum tolerated dose }
\end{aligned}
$$

\section{OECD 423 Guidelines for acute toxicity study}

The MLETI was tested for its acute toxicity in rats and mice. Acute toxicity studies were performed according to OECD, (2002) 423 guidelines. To determine short term toxicity, the adult Wistar rats and mice were starved overnight and were administered the extract orally in increasing dose levels of 300, 500, 2000, 5000 and $8000 \mathrm{mg} / \mathrm{kg}$ body weight. The mortality and general behavior of the animals were observed periodically for $48 \mathrm{~h}$. The animals were observed individually after dosing periodically for $24 \mathrm{~h}$ with special attention during first two hours and then intermittently thereafter, for a total period of 14 days. The animals were observed for the signs of toxicity which include changes in eyes and mucous membrane, skin, fur and behavior pattern. Attention was given to parameters like grooming, hyperactivity, convulsions, tremors, salivation, lethargy, diarrhea, loss of righting, reflex, sleep and coma (Hivrale et al., 2013).

\section{Analgesic Studies}

Acetic acid-induced writhing test in mice

The test was carried out as described by Koster and Anderson, (1959) and Correa et al., 1996. Thirty mice were randomized into 5 groups of 6 mice each and treated with normal saline $(10 \mathrm{~mL} / \mathrm{kg})$, graded doses $(50,100$ and $200 \mathrm{mg} / \mathrm{kg}$ body weight) of extract, and standard drug (10 mg ketoprofen/ $\mathrm{kg}$ body weight) orally. After 1 hour of treatment, $0.2 \mathrm{ml}$ of $0.7 \%$ acetic acid was administered to each mouse intraperitoneally (IP). The number of abdominal writhing movements was counted after 5 minutes for 30 minutes. Anti-nociception (analgesia) was expressed as the reduction in the number of abdominal constrictions between control and extract treated mice. Percentage inhibition was then calculated in relation to the control.

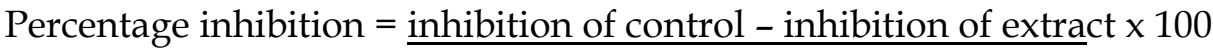 Inhibition of extract}

\section{Hot plate-induced pain in mice}

The mice were selected based on their pain threshold. The hot plate temperature was maintained at $55 \pm 1{ }^{\circ} \mathrm{C}$ and each mouse was placed in a glass beaker of $50 \mathrm{~cm}$ diameter on the heated surface and mice that responded within $2 \mathrm{sec}$ were selected. Thirty selected mice were divided into 5 groups of 6 mice each and pre-treated with normal saline $(10 \mathrm{~mL} / \mathrm{kg})$, graded doses (50, 100 and $200 \mathrm{mg} / \mathrm{kg}$ body weight) of extract and standard drug (10 mg ketoprofen $/ \mathrm{kg}$ body weight) orally. The response time was measured one hour after extract or drug administration and subsequently at 30 minutes interval for a total of 150 minutes. The time(s) between placement and hind paw lifting/licking or jumping was recorded as the index of response latency (Choi et al., 2005).

Formalin-induced hind-paw licking in Wistar rats

Rats were fasted overnight before the commencement of the experiment, but allowed access to water ad libitum. Rats in group 1 (negative control) received $10 \mathrm{ml} / \mathrm{kg}$ of normal saline, 
groups II-IV received graded doses (50, 100 and $200 \mathrm{mg} / \mathrm{kg}$ body weight) of the extract while the positive control received $10 \mathrm{mg} / \mathrm{kg}$ pentazocine respectively as in the study design. One hour after extract and drug administration, $50 \mu l$ of $2.5 \%$ formalin was injected subcutaneously into the sub-plantar surface of the left hind paw of each rat. They were placed in an observation chamber and maximum pain responses were scored every 1 minute for the first 5 minutes after formalin injection (first phase) and every 5 minutes between 15 40 minutes after formalin injection (second phase) (Hunskaar et al., 1987; Tjølsen et al., 1992 ). The severity of pain response was recorded for each rat based on the following scale:

$0 \quad$ = rat walked or stood firmly on the injected paw

1 = partial elevation or light weight bearing of the injected paw on the floor

2 = elevation of the injected paw without contact with the floor

3 = shaking or licking or biting of the injected paw.

\section{Data Analysis}

Data was analysed using statistical software. All quantitative data were expressed as the mean \pm standard error of mean (SEM). Significant difference between means were assessed using one way analysis of variance (ANOVA), at 95\% level of significant i. e. $p$-value less than $0.05(p<0.05)$ was considered significant. Dunnett's post hoc test was carried out to determine where the level of significance lay.

\section{RESULTS}

\section{Plant Extract}

The methanol leaves extract of T. indica (MLETI) yielded $19.9 \% \mathrm{w} / \mathrm{w}$, solid brownish powder which was water-insoluble except when mixed with tragacanth, a suspending agent.

Qualitative determination of phytochemicals of MLETI

The qualitative phytochemical screening of the MLETI revealed the presence of glycosides, flavonoids, saponins, alkaloids, reducing sugars, steroids and terpenoids (Table 1).

Quantitative determination of phytochemicals of MLETI

The quantitative determination of the phytochemicals present in the MLETI showed that $100 \mathrm{~g}$ of the plant material contained $1.26 \mathrm{~g} 0.00(12.6 \%)$ of flavonoids, $6.7 \mathrm{~g} \pm 0.01(12.9 \%)$ of alkaloids, $0.004 \mathrm{~g} \pm 0.00(0.9 \%)$ of cyanogenic glycosides, $0.30 \mathrm{~g} \pm 0.02(1.48 \%)$ saponins and $0.28 \mathrm{~g} \pm 0.01(9.6 \%)$ of tannins (Table 2$)$.

Table 1 Qualitative Determination of Phytochemicals of MLETI

\begin{tabular}{llc}
\hline Constituents & Test & Inference \\
\hline Glycosides & Keller-killains test & + \\
Flavonoids & Shinodas test & + \\
Saponins & Frothing test & + \\
Alkaloids & Dragendorffs test & + \\
Anthraquinones & Borntrages test & - \\
Phlabotanins & & - \\
Reducing sugar & Barfoeds test & + \\
Volatile oil & & - \\
Tannins & Lead sub-acetate test & - \\
Steroids & Liebermann-Burchard test & + \\
Terpenoids & Liebermann-Burchard test & + \\
\hline
\end{tabular}

Symbol (+) and (-) shows presence and absence of the active constituents in the extract. MLETI: Methanol Leaves Extract of Tamarindus indica.

Table 2. Quantitative Determination of Phytochemicals in 100g of MLETI

$\begin{array}{lll}\text { Phytochemicals } & \text { Amount }(\mathrm{g}) & \text { Percentage Yield }\end{array}$




\begin{tabular}{ccc}
\hline Flavonoid & $12.6 \pm 0.01$ & 12.60 \\
Saponins & $3.0 \pm 0.02$ & 1.48 \\
Alkaloids & $6.7 \pm 0.01$ & 12.90 \\
Cynogenic glycosides & $1.00 \pm 0.00$ & 0.90 \\
Tannins & $2.8 \pm 0.01$ & 9.60 \\
\hline \multicolumn{2}{c}{ Values are expressed in mean \pm SEM $(\mathrm{n}=3)$}
\end{tabular}

\section{Acute Toxicity Study}

Lorke's method for acute toxicity study

In phase I of the experiment, animals treated with $1000 \mathrm{mg} / \mathrm{kg}$ of the extract showed immediate signs of toxicity that included initial restlessness with writhing abdominal movement that was followed by decrease in physical activity (sedation) associated with mild respiratory distress but were reversed thereafter within the first-four hours. All the animals in the different dose groups were monitored for 14 days and no mortality was recorded. Similar signs of toxicity (decreased physical activity and respiratory distress) manifested in all the groups and doses used in the second phase, and were also reversed within the firstfour hours of extract administration. No mortality was recorded in the animals at all dose levels used in the 2 phases.

OECD 423 guidelines for acute toxicity study

As suggested by OECD, (2002) guidelines, the test animals were observed individually, after dosing at once during first $30 \mathrm{~min}$, periodically during the first $24 \mathrm{~h}$ with special attention during first $2 \mathrm{~h}$. The test animals did not exhibit any visible change and survived beyond recommended duration of observation with $8000 \mathrm{mg} / \mathrm{kg}$.

\section{Analgesic Activity}

Acetic acid induced writhing test in mice

The MLETI at doses of 50, 100, and $200 \mathrm{mg} / \mathrm{kg}$ produced significant $(p<0.001)$ and dosedependent reduction in acetic acid induced writhes in the treated mice compared to control by $33.6 \%, 35.5 \%$ and $47.2 \%$ respectively (Table 3 ). Ketoprofen, the standard drug used also produced significant $(p<0.001)$ reduction similar to the extract but at the rate of $65.7 \%$ compared to the control.

Table 3. Effect of MLETI on Acetic Acid-Induced Writhes in Mice

\begin{tabular}{ccc}
\hline Treatment (p.o.) & $\begin{array}{c}\text { Mean no. of writhes } \pm \text { SEM } \\
(30 \mathrm{mins})\end{array}$ & \% inhibition \\
\hline N. saline $(10 \mathrm{~mL} / \mathrm{kg})$ & $64.80 \pm 3.97$ & 0 \\
MLETI $(50 \mathrm{mg} / \mathrm{kg})$ & $43.00 \pm 3.48^{\mathrm{a}}$ & 33.6 \\
MLETI $(100 \mathrm{mg} / \mathrm{kg})$ & $41.80 \pm 1.93^{\mathrm{a}}$ & 35.5 \\
MLETI $(200 \mathrm{mg} / \mathrm{kg})$ & $34.20 \pm 2.65 \mathrm{a}$ & 47.2 \\
Ketoprofen $(10 \mathrm{mg} / \mathrm{kg})$ & $22.20 \pm 3.31^{\mathrm{a}}$ & 65.7 \\
\hline
\end{tabular}

Values are expressed in mean \pm SEM $(n=6)$; a $\leq \leq 0.001$, as compared to normal saline-One-way ANOVA test followed by Dunnett's multiple tests for comparison. MLETI: Methanol Leaves extract of T. indica.

\section{Hot plate-induced pain test}

The MLETI at doses of 50, 100 and $200 \mathrm{mg} / \mathrm{kg}$ caused an increase in the mean reaction time (MRT) to thermal stimulus dose-dependently with percentage mean protection effect (\%MPE) of 17.8, 34.1 and $64.9 \%$ respectively. All doses of extract produced statistically significant $(p<0.05)$ antinociceptive effects compared to control while the reference drug, ketoprofen $(10 \mathrm{mg} / \mathrm{kg})$ produced highly significant $(p<0.001)$ antinociceptive effect compared to control with percentage mean protection effect of $74.6 \%$ (Table 4 ). 
Table 4. Effect of MLETI in Hot Plate Reaction in Mice

\begin{tabular}{ccc}
\hline Treatment (o.p.) & Mean time \pm SEM & \% MPE \\
mg/kg & $(\mathrm{sec})$ & 0 \\
\hline N/ saline (10 ml) & $1.85 \pm 0.19$ & 17.8 \\
MLETI (50) & $2.18 \pm 0.68^{\mathrm{a}}$ & 34.1 \\
MLETI (100) & $2.48 \pm 0.21^{\mathrm{a}}$ & 64.9 \\
MLETI (200) & $3.05 \pm 0.38^{\mathrm{a}}$ & 74.6 \\
\hline Ketoprofen (10) & $3.23 \pm 0.26^{\mathrm{b}}$ & \\
\hline
\end{tabular}

Values are expressed in mean \pm SEM $(\mathrm{n}=6) ; \mathrm{a} p<0.05, \mathrm{~b} p<0.001$ as compared to normal saline- One-way ANOVA test followed by Dunnett's multiple tests for comparison. MLETI: Methanol Leaves extract of T. indica.

Formalin-induced paw licking test in rats

The MLETI inhibited formalin-induced paw licking response in rats more significantly in the second phase $(p<0.001)$ at all doses used compared to control. The standard drug, pentazocine $(10 \mathrm{mg} / \mathrm{kg})$ also significantly $(p<0.001)$ reduced pain response in both early and second phases compared to control (Table 5).

Table 5. Effect of MLETI on Formalin Induced Paw Lick Test in Rats

\begin{tabular}{|c|c|c|c|}
\hline \multirow{6}{*}{$\begin{array}{l}\text { Values are } \\
\text { in mean } \pm \\
\text { a } p<0.05, \\
\text { compared } \\
\text { saline-One- } \\
\text { ANOVA } \\
\text { followed } \\
\text { Dunnett's }\end{array}$} & Treatment $(\mathrm{mg} / \mathrm{kg})$ & Pain Severity Early phase & $\begin{array}{c}\text { Score } \\
\text { Late phase }\end{array}$ \\
\hline & $\mathrm{N} /$ saline $(10 \mathrm{ml})$ & $2.90 \pm 0.08$ & $3.00 \pm 0.00$ \\
\hline & MLETI 50 & $2.52 \pm 0.19 a$ & $1.48 \pm 0.23^{b}$ \\
\hline & MLETI 100 & $2.32 \pm 0.05^{\mathrm{a}}$ & $1.44 \pm 0.07 b$ \\
\hline & MLETI 200 & $2.04 \pm 0.21^{b}$ & $0.28 \pm 0.08^{b}$ \\
\hline & Pentazocine 10 & $2.16 \pm 0.07 \mathrm{~b}$ & $1.40 \pm 0.45^{b}$ \\
\hline
\end{tabular}

tests for comparison. MLETI: Methanol Leaves extract of T. indica.

\section{DISCUSSION}

The qualitative phytochemical screening of MLETI revealed the presence of alkaloids, glycosides, flavonoids, saponins, reducing sugars, steroids and terpenoids. These are secondary metabolites of plants with potent biological activities, while the quantitative determination of the phytochemicals present in the MLETI showed that $100 \mathrm{~g}$ of the plant material contained flavonoids, alkaloids, cyanogenic glycosides, saponins and tannins. Alkaloids have been shown to have higher percentage yield, followed by flavonoids, tannins, saponins and glycosides. Previous research shows that some alkaloids have centrally-mediated analgesic and anti-plasmodial activities (Elisabetsky et al., 1995; Elisabetsky et al., 2006; de Moura et al., 2008). Flavonoids, alkaloids and saponins have been previously reported to have pronounced anti-nociceptive activity (Hunskaar et al., 1987; Choi et al., 2005). A study by Sawant et al., (2004) reported that the total alkaloid fractions of Eclipta alba were responsible for its central and peripheral analgesic activities while Annegowda et al., (2010) reported that flavonoids show analgesic activity by enhancing the endogenous serotonin level or interact with 5-HT2A and 5-HT3 receptors.

Survival of the animals at all dose levels used in the 2 phases of the study after 14 days of extract administration indicates that the extract is safe. Lorke, (1983) classified chemical toxicity based on oral median lethal dose $\left(\mathrm{LD}_{50}\right)$ values as follows; substances with $\mathrm{LD}_{50} \geq 1$ $\mathrm{mg} / \mathrm{kg}$ are considered to be highly toxic, $\mathrm{LD}_{50} \geq 5 \mathrm{mg} / \mathrm{kg}$ are considered to be toxic, $\mathrm{LD}_{50} \geq$ $100 \mathrm{mg} / \mathrm{kg}$ are considered moderately toxic, $\mathrm{LD}_{50} \geq 1000 \mathrm{mg} / \mathrm{kg}$ are considered to be slightly toxic while substance with $\mathrm{LD}_{50} \geq 5000 \mathrm{mg} / \mathrm{kg}$ are considered to be non-toxic. In this study, the oral LD $\mathrm{L}_{50}$ value of MLETI was found to be greater than $5000 \mathrm{mg} / \mathrm{kg}$ body weight in both mice and Wistar rats, suggesting that the extract is non-toxic when administered acutely. 
The test animals did not exhibit any visible change and survived beyond recommended duration of observation with $8000 \mathrm{mg} / \mathrm{kg}$. Hence, MLETI was safe up to $8000 \mathrm{mg} / \mathrm{kg}$ as confirmed by OECD 423 guideline.

The peripheral analgesic activity of the extract was evaluated using acetic acid-induced writhing test (Su et al., 2011), which is able to detect antinociceptive effect of compounds at dose levels that may appear inactive in other methods like tail flick test (Collier et al., 1968). Injection of acetic acid into the peritoneal cavity of mice triggers the release of a variety of mediators that include substance $\mathrm{P}$, bradykinins and prostaglandins especially $\mathrm{PGE}_{2}$ and $\mathrm{PGF}_{2 a}$ (Deraedt et al., 1980). These substances activate the chemo-sensitive nociceptors that play a role in the development of typical inflammatory pain response characterized by an arching of back, extension of hind limbs and contraction of abdominal musculature. These chemosensitive nociceptive receptors are sensitive to non-steroidal anti-inflammatory drugs (NSAIDS) like aspirin, indomethacin and ketoprofen (Pinheiro et al., 2010), the standard drug used in this research. NSAIDs inhibit the conversion of arachidonic acid to the unstable intermediate endoperoxide, prostaglandin $\mathrm{H}_{2}$ (PGH2), the common substrate for a number of different synthetases that produce many lipid mediators including the major prostaglandins (PGs), prostaglandin $\mathrm{E}_{2}\left(\mathrm{PGE}_{2}\right)$, prostaglandin $\mathrm{D}_{2}\left(\mathrm{PGD}_{2}\right)$ and prostaglandin $\mathrm{F}_{2}$ alpha $\left(\mathrm{PGF}_{2} \mathrm{a}\right)$ as well as thromboxane and prostacyclin $\left(\mathrm{PGI}_{2}\right)$. The leaf extract significantly $(p<0.05)$ reduced the acetic acid induced writhing in treated mice but dosedependently. This shows that $T$. indica possesses peripheral anti-nociceptive activity in the mice probably by an action that may be linked to the inhibition of cyclo-oxygenases and/or lipoxygenases.

The hot plate test is specific for centrally mediated nociception (Parkhouse et al., 1979) and is suitable for evaluation of centrally but not peripherally acting analgesics. The heated plate at constant temperature produced two behavioral components that were measured in terms of their reaction times as paw licking/withdrawal and jumping which are considered to be supra-spinally integrated responses. The leaf extract significantly $(p<0.05)$ and dosedependently protected the mice against hot plate induced pain by prolonging the reaction latency time. These revealed that the methanol leaf extract of $T$. indica also possesses centrally mediated analgesic activity in the mice.

Formalin test is a model of acute pain which could discriminate between central and/or peripheral components of pain. Centrally acting agents inhibit both early and late phases almost equally (Vogel and Vogel, 1997) while peripherally acting agents inhibit only the late phase (Elisabetsky et al., 1995; de Moura et al., 2008). The early phase of the nociceptive response which normally peaks 5 minutes after formalin injection corresponds to the neurogenic pain. This was due to direct chemical stimulation of the nociceptors which are transmitted via C-fibres and can be suppressed by opioids such as pentazocine (Sayyah et al., 2004). The second (late) phase which peaks 15-30 minutes after formalin injection represents the inflammatory/peripheral pain response mediated by cytokines such as serotonins, histamine, prostaglandins (Hunskaar et al., 1987; Tjølsen et al., 1992). The extract significantly $(p<0.0 .5)$ and dose-dependently inhibited both the neurogenic (early phase) and inflammatory (second phase) pain responses. The inhibitory effect was significantly more pronounced in the second phase $(p<0.001)$ as compared to the early phase $(p<0.05)$, showing that the extract was more effective on inflammatory (peripheral) than centrallymediated pain. 


\section{CONCLUSION}

The methanol leaf extract of $T$. indica possesses phytochemical constituents that may be responsible for centrally and peripherally mediated analgesic activities. These findings provide more scientific evidence for the ethnomedicinal use of $T$. indica leaf in the management of pains.

\section{REFERENCES}

Abdelrahman, G. H., Mariod, A. A. (2019). Tamarindus indica: Phytochemical constituents, bioactive compounds and traditional and medicinal uses. Wild Fruits: Composition, Nutritional Value and Products: Springer. p. 229-38.

Abubakar, M., Yerima, M., Zahriya, A., Ukwuani, A. (2010). Acute toxicity and antifungal studies of ethanolic leaves, stem and pulp extract of Tamarindus indica. Research Journal of Pharmaceutical, Biological and Chemical Sciences, 1(4):104-11.

Annegowda, H., Mordi, M., Ramanathan, S., Mansor, S. (2010). Analgesic and antioxidant properties of ethanolic extract of Terminalia catappa L. leaves. International journal of pharmacology, 6(6):910-15.

Azad, S. (2018). Tamarindo-Tamarindus indica. Exotic fruits: Elsevier; 2018. p. 403-12.

Bohm, B., A. (1998). Introduction to flavonoids: Harwood Academic Publishers; 1998.

Chimsah, F., Nyarko, G., Abubakari, A. (2020). A review of explored uses and study of nutritional potential of tamarind (Tamarindus indica L.) in Northern Ghana. African Journal of Food Science, 14(9):285-94.

Choi, J., Jung, H. J., Lee, K. T., Park, H. J. (2005). Antinociceptive and anti-inflammatory effects of the saponin and sapogenins obtained from the stem of Akebia quinata. Journal of Medicinal Foods, 8(1):78-85.

Collier, H., Dinneen, L., Johnson, C. A., Schneider, C. (1968). The abdominal constriction response and its suppression by analgesic drugs in the mouse. British Journal of Pharmacology and Chemotherapy 1968, 32(2):295-310.

Coronel, R. E. (1991). Plant Resources of South East Asia, Wageningen, Pudoc. No.2. Edible fruits and nuts. PROSEA Foundation. Bogor, Indonesia: PROSEA Foundation; 1991. p. 298-301.

Corrêa, C. R., Kyle, D. J., Chakraverty, S., Calixto, J. B. (1996). Antinociceptive profile of the pseudopeptide B2 bradykinin receptor antagonist NPC 18688 in mice. British Journal of Pharmacology, 117(3):552-58.

de Moura, Linck, V., Herrmann, A. P., Goerck GC, Iwu MM, Okunji CO, Leal MB, et al. The putative antipsychotic alstonine reverses social interaction withdrawal in mice. Progress in Neuropsychopharmacology and Biological Psychiatry, 32(6):1449-52.

Deraedt, R., Jouquey, S., Delevallée, F., Flahaut, M. (1980). Release of prostaglandins E and F in an algogenic reaction and its inhibition. European Journal of Pharmacology, 61(1):1724.

Diallo, D. A., Sutherland, C. Nebié, I., Konaté, A. T., Ord, R., Ilboudo-Sanogo, E, et al. (2007). Children in Burkina Faso who are protected by insecticide-treated materials are able to clear drug-resistant parasites better than unprotected children. The Journal of infectious diseases, 196(1):138-44.

Elisabetsky, E., Amador, T. A., Albuquerque, R. R., Nunes, D. S., do, C. T., Carvalho, A. (1995). Analgesic activity of Psychotria colorata (Willd. ex R. \& S.) Muell. Arg. alkaloids. Journal of Ethnopharmacology, 48(2):77-83.

Elisabetsky, E., Costa-Campos, L. (2006). The alkaloid alstonine: a review of its pharmacological properties. Evidence Based Complementary Alternative Medicine 3(1):39-48.

Evans, W. C. (2009). Trease and evans' pharmacognosy E-book: Elsevier Health Sciences 
Fabiyi, J., Kela, S., Tal, K., Istifanus, W. (1993). Traditional therapy of dracunculiasis in the state of Bauchi-Nigeria. Dakar Medical, 38(2):193-5.

Ferrara, L. (2005). Antioxidant activity of Tamarindus indica L. Ingredienti Alimentari (Italy) 2005.

Harborne, J., B. (1973). A guide to modern techniques of plant analysis: Chapman and Hall.

Hivrale, M., Bandawane, D., Mali, A. (2013). Anti-inflammatory and analgesic activities of petroleum ether and ethyl acetate fractions of Tamarindus indica seeds. Oriental Pharmacy and Experimental Medicine, 13(4):319-26.

Hunskaar, S., Hole, K. (1987). The formalin test in mice: dissociation between inflammatory and non-inflammatory pain. Pain, 30(1):103-14.

Khan, M. A., Muheet-e-Azam. (2012) . New Delhi: India offset press, CCRUM,; 2012.

Khanzada SK, Shaikh W, Sofia S, Kazi T, Usmanghani K, Kabir A, et al. (2008). Chemical constituents of Tamarindus indica L. medicinal plant in Sindh. Pakistan Journal of Botany, 40(6):2553-59.

Koster, R. and Anderson, M. (1959). Acetic acid for analgesic screening. Federation Proceeding, 18, 412.

Lewis, W. H., Elvin-Lewis, M. P. (2003). Medical botany: plants affecting human health: John Wiley \& Sons; 2003.

Lorke, D. (1983). A new approach to practical acute toxicity testing. Archives of Toxicology; 54(4):275-87.

Meher, B., Dash, D. K., Roy, A. (2014). A review on: Phytochemistry, pharmacology and traditional uses of Tamarindus indica L. World Journal of Pharmacy and Pharmaceutical Science, 3(10):229-40.

Naeem, N., Nadeem, F., Azeem, M. W., Dharmadasa, R. (2017). Tamarindus indica-A Review of Explored Potentials. International Journal of Chemical and Biochemical Sciences, 12:98106.

OECD. (2002). Guidelines for the Testing of Chemicals / Section 4: Health Effects Test No. 423: Acute Oral toxicity - Acute Toxic Class Method. Organization for Economic Cooperation and Development, Paris, France.

Onwuka, G. I. (2005). Food analysis and instrumentation: theory and practice: Napthali prints.

Parkhouse, J., Pleuvry, B., Rees, J. (1979). Analgesic drugs: Blackwell Scientific Publications Oxford.

Pearson, D. (1976). Chemical analysis of food. Churchill Livingstone. Edinburgh, United Kingdom

Pinheiro, M. M., Bessa, S. O., Fingolo, C. E., Kuster, R. M., Matheus, M. E., Menezes, F. S et al., (2010). Antinociceptive activity of fractions from Couroupita guianensis Aubl. leaves. Journal of Ethnopharmacology, 127(2):407-13.

Sawant, M, Isaac, J. C., Narayanan, S. (2004). Analgesic studies on total alkaloids and alcohol extracts of Eclipta alba (Linn.) Hassk. Phytotherapy Research, 18:111-113.

Sayyah, M., Hadidi, N., Kamalinejad, M. (2004). Analgesic and anti-inflammatory activity of Lactuca sativa seed extract in rats. Journal of Ethnopharmacology, 92(2-3):325-29.

Sofowora, A. (1993). Screening plants for bioactive agents. Medicinal Plants and Traditional Medicinal in Africa 2nd Ed Spectrum Books Ltd, Sunshine House, Ibadan, Nigeria 1993:134-56.

Su, S., Wang, T., Duan, J. A., Zhou, W., Hua, Y. Q., Tang, Y. P. et al., (2011). Antiinflammatory and analgesic activity of different extracts of Commiphora myrrha. 134(2):251-58.

Tjølsen, A., Berge, O. G., Hunskaar, S., Rosland, J. H., Hole, K. (1992). The formalin test: an evaluation of the method. Pain, 51(1):5-17. 
Vogel, G., Vogel, W. (1997). Drug discovery and evaluation: pharmacological assays springer-Verlag. Berlin: Germany.

Walker, A. F., Marakis, G., Simpson, E., Hope, J. L., Robinson, P. A., Hassanein, M et al. (2006). Hypotensive effects of hawthorn for patients with diabetes taking prescription drugs: a randomized controlled trial. The British Journal of General practice: The Journal of the Royal College of General Practitioners, 56(527):437-43.

Williams, S. (1984). Official methods of analysis of the Association of Official Analytical Chemists. Association of Official Analytical Chemists, Inc., 19840935584242. 